\title{
Occurrence of myo-inositol-1-phosphate phosphatase in pteridophytes: characteristics of the enzyme from the reproductive pinnules of Dryopteris filix-mas (L.) Schott
}

\author{
Ritwika Banerjee ${ }^{1}$, Dhani R. Chhetri ${ }^{2}$ and Jukta Adhikari ${ }^{1 *}$ \\ ${ }^{1}$ Post-Graduate Department of Botany, Presidency College, 86/1 College Street, Kolkata - 700073, India. ${ }^{2}$ Post-Graduate Department \\ of Botany, Darjeeling Govt. College, Darjeeling - 743101, India. *Corresponding author: adhikarijukta@gmail.com
}

Received: 04 April 2007; Returned for revision: 02 July 2007; Accepted: 30 July 2007

Evident myo-inositol-1-phosphate phosphatase (MIPP) activity has been detected both in the vegetative as well as in the spore-bearing organs of some selected pteridophytes having wide phylogenetic diversity. The basic characterization of this enzyme was carried out using the cosmopolitan fern Dryopteris filix-mas. The enzyme was partially purified from the cytosol fraction obtained from the reproductive pinnules of the plant to about 41 -fold over the initial homogenate following low-speed centrifugation, streptomycin sulfate precipitation, 25-70\% ammonium sulfate fractionation, CM Sephadex C-50 chromatography and finally gel-filtration on Ultrogel AcA 34. The apparent molecular weight of the native MIPP was estimated to be $94 \mathrm{kDa}$. The enzyme activity increased linearly with respect to protein concentration to about $150 \mu \mathrm{g}$ and with respect to time up to $75 \mathrm{~min}$. The temperature optimum was found at $40^{\circ} \mathrm{C}$. However, the enzyme showed good activity over the temperature range of $30-50^{\circ} \mathrm{C}$. This enzyme used D/L-myo-inositol1-phosphate as its principal substrate (95-100\%), however, about 16\% activity was recorded when D-myo-inositol-3phosphate substituted as substrate. Furthermore, weak (3\%) activity of this MIPP was observed with 2glycerophosphate as substrate. The apparent $K_{m}$ for pteridophytic MIPP was $0.083 \mathrm{mM}$. The enzyme was functional in a narrow $\mathrm{pH}$ range of 7.5 to 8.5 . The activity of this MIPP enzyme was remarkably inhibited by the presence of a monovalent cation, lithium, and even moderately so at a low concentration such as $1 \mathrm{mM}$. On the other hand, magnesium, a divalent cation, enhanced activity at least up to $10 \mathrm{mM}$. Calcium diminished MIPP activity at concentrations over $4 \mathrm{mM}$.

Key words: Dryopteris filix-mas, myo-inositol-1-phosphate phosphatase, pteridophytes, reproductive pinnules

Ocorrência da fosfatase do mio-inositol-1-fosfato em pteridófitas: características da enzima a partir de pínulas reprodutivas de Dryopteris filix-mas (L.) Schott: Tem-se detectado atividade da fosfatase do mio-inositol-1-fosfato (FMIF) tanto em órgãos vegetativos como em estruturas esporulantes de algumas pteridófitas com ampla diversidade filogenética. Neste estudo, procedeu-se à caracterização básica dessa enzima utilizando-se da pteridófita cosmopolita Dryopteris filix-mas. Após centrifugação em baixa velocidade, precipitação com sulfato de estreptomicina, fracionamento com sulfato de amônio (25-70\%), cromatografia em CM Sephadex C-50 e, finalmente, filtração gélica em Ultrogel AcA 34, conseguiu-se uma purificação parcial da enzima (a partir da fração citossólica obtida de pínulas reprodutivas da planta) de cerca de 41 vezes em relação ao homogenato inicial. O peso molecular aparente da FMIF nativa foi estimado em $94 \mathrm{kDa}$. A atividade da enzima aumentou linearmente com relação ao conteúdo de proteína (cerca de $150 \mu \mathrm{g}$ ) e com relação ao tempo (até $75 \mathrm{~min}$ ). A temperatura ótima foi de $40^{\circ} \mathrm{C}$. Entretanto, a enzima exibiu atividade razoável na faixa de temperatura entre 30 e $50^{\circ} \mathrm{C}$. O D/L-mio-inositol-1-fosfato foi o principal substrato (95-100\%) da enzima, porém registrou-se uma atividade de cerca de $16 \%$ quando este composto foi substituído pelo D-mio-inositol-3fosfato. Ademais, observou-se fraca atividade (3\%) da FMIF quando se utilizou o 2-glicerol-fosfato como substrato. O 
$K_{m}$ aparente para a enzima foi $0,083 \mathrm{mM}$. A enzima mostrou-se funcional numa estreita faixa de $\mathrm{pH}(7,5$ a 8,5$)$. Sua atividade foi fortemente inibida pelo lítio, um cátion monovalente; mesmo a concentrações baixas ( $1 \mathrm{mM})$, o lítio inibiu moderadamente a atividade da FMIF. Por outro lado, o magnésio, um cátion divalente, aumentou a atividade da enzima, no mínimo até a concentrações de $10 \mathrm{mM}$. O cálcio diminuiu a atividade da FMIF em concentrações superiores a $4 \mathrm{mM}$. Palavras-chave: Dryopteris filix-mas, fosfatase do mio-inositol-1-fosfato, pínulas reprodutivas, pteridófitas

\section{INTRODUCTION}

Inositols belong to a larger class of polyhydroxylated cycloalkanes, commonly known as cyclitols. Among the nine possible geometrical isomers of inositol, the myoform is the most abundant in biological systems where it functions as an essential metabolite. It is present in a large number of organisms from microbial systems to higher plants and animals (IUPAC, 1976). Biosynthesis of myo-inositol is dependent on two enzymes. D-glucose-6phosphate is irreversibly isomerised to L-myo-inositol-1phosphate by a $\mathrm{NAD}^{+}$-dependent oxido-reductase, Lmyo-inositol-1-phosphate synthase [EC 5.5.1.4; Dglucose-6-phosphate-1L-myo-inositol-1-phosphate synthase (MIPS)] and the product of this enzymatic reaction (L-myo-inositol-1-phosphate) generates free myo-inositol on hydrolysis by a specific $\mathrm{Mg}^{2+}$-dependent phosphatase, myo-inositol-1-phosphate-phosphatase [EC 3.1.3.25; D/L-myo-inositol-1-phosphate phosphohydrolase, (MIPP)]. Inositol metabolism is indispensable for the development of plants, animals and some microorganisms being related with a large number of cellular and metabolic events. The crucial role of inositol in many cellular processes including membrane formation, cell wall biogenesis, stress response and signal transduction have been well documented (Lackey et al., 2003). Myo-inositol is the precursor of all inositolcontaining compounds including phosphoinositides and inositol phosphates. Therefore, the variation in cellular concentration of myo-inositol is largely dependent upon the onset, offset and toggling between these two events by enzymatic regulations centered on MIPS and MIPP. Generation of free myo-inositol may be blocked if MIPP is not active. The MIPS reaction has been reported to occur in a large number of living systems namely archea (Chen et al., 2000), bacteria (Bachhawat and Mande, 2000), protozoa (Lohia et al., 1999), lower plants (Donahue and Henry, 1981a,b; Escamilla et al., 1982; Dasgupta et al., 1984; RayChoudhury et al., 1997; Benaroya et al., 2004,
Chhetri et al., 2005), higher plants (Loewus and Loewus, 1971; Loewus et al., 1978; Ogunyemi et al., 1978; Adhikari et al., 1987; Johnson and Sussex, 1995; Johnson and Wang, 1996; Chun et al., 2003), and animals (Pittner and Hoffmann-Ostenhof, 1976; Maeda and Eisenberg Jr., 1980; Adhikari and Majumder, 1983, 1988; Chiu et al., 2003). In pteridophytes, Benaroya et al. (2004) and Chettri et al. $(2005,2006)$ have recently documented the occurrence and characterization of L-myo-inositol-1phosphate synthase. So far, work with regard to the participation of the subsequent enzyme in this metabolic sequence, myo-inositol-1-phosphate phosphatase (MIPP), has been carried out principally in animal systems (Eisenberg Jr, 1967; Attwood et al., 1988; Gee et al., 1988; Honchar et al., 1989; Leech et al., 1993; Pollack et al., 1994; Kwok and Lo, 1994; Fujimoto et al., 1996; Caselli et al., 1996), in archaea (Wang et al., 2006), in bacteria (Nigou and Besra, 2002), and in cyanobacteria (Patra et al., 2007). However, only a few reports are available of this enzyme from plant systems (Loewus and Loewus, 1983; Gumber et al., 1984). Therefore, although the inositol biosynthetic pathway is necessarily functional in the vascular cryptogams, the supporting evidence is based only on MIPS (Chhetri et al., 2005, 2006) without any information on MIPP. Hence the present investigation on MIPP is an attempt to bridge that gap and proceed with the study of this biosynthetic pathway through the evolutionary scale in pteridophytes centered on myoinositol.

\section{MATERIAL AND METHODS}

Plant material: Experimental specimens of pteridophytes namely Lycopodium clavatum L., Selaginella megaphylla Bak., Eqisetum elongatum Willd., Polypodium wallichi R. Br., Diplopterygium glaucum (Thunb.) Nakai, Pteridium aquilinum (L.) Kuhn. and Dicranopteris linearis Bedd. were collected freshly from 
their natural habitats in and around the Darjeeling hills (ca. $2134 \mathrm{~m}$ a.s.1.) in the Eastern Himalayas. The specimens were kept frozen until use. Dryopteris filixmas (L.) Schott, the principal specimen of this present investigation, was collected fresh from the localities in and around Thakurpukur, Kolkata, West Bengal, India. All experiments were carried out three times independently using different batches of partially purified enzyme.

Chemicals: D-myo-Inositol-1-phosphate (monosodium salt) and D-myo-inositol-3-phosphate (sodium salt) were purchased from Cayman Chemical, USA. D-glucose-6P (G-6$\mathrm{P}$, di-sodium salt), D-galactose-6P (di-sodium salt), Dfructose-6P (di-sodium salt), CM Sephadex C-50 (C50120), Ultrogel AcA 34 (U8878), dialysis bags, Coomassie Brilliant Blue G-250, Coomassie Brilliant Blue R-250 and BSA, were obtained from Sigma-Aldrich, USA. Protein molecular weight markers, namely Myosin rabbit muscle, Phosphorylase b, ovalbumin, and carbonic anhydrase were purchased from Genei, Bangalore, India. L-myo-inositol-1phosphate was prepared in this laboratory according to the method of Eisenberg Jr. (1967) on a small scale. 2mercaptoethanol (ME), ammonium molybdate, acetic acid, ammonium sulphate, sodium hydroxide, potassium chloride, sodium carbonate, copper sulfate, lithium chloride, calcium chloride, magnesium chloride, Tris, trichloroacetic acid (TCA) and di-potassium hydrogen phosphate were purchased from E. Merck India Ltd., Mumbai, India. Ascorbic acid was from Sisco Research Laboratories, Mumbai, India. All other chemicals used were of analytical grade purchased from reputed Indian companies.

Isolation and partial purification of MIPP: Sample(s) (10 g each) of plant material were washed twice with cold glass-distilled water and homogenized in a chilled mortar and pestle in two volumes of $50 \mathrm{mM}$ Tris-HCl buffer $(\mathrm{pH}$ 7.0) containing $0.2 \mathrm{mM}$ of $\mathrm{ME}$ (hereafter referred to as standard buffer). Thereafter all the operations were carried out at $4^{\circ} \mathrm{C}$. The crude homogenate was passed through three layers of muslin and the filtrate centrifuged at $1000 \mathrm{~g}$ for $5 \mathrm{~min}$. The supernatant was again centrifuged at $11,400 \mathrm{~g}$ for $20 \mathrm{~min}$ in a Plasto Crafts Superspin-R centrifuge and the pellet discarded. The supernatant was dialyzed overnight against the standard buffer and the clear supernatant collected from the dialysis bag. This preparation was used for the basic screening experiments of all the specimens. Partial purification of MIPP was carried out using the mature reproductive pinnules of Dryopteris filix-mas going through the initial steps mentioned earlier followed by the successive purification steps. The $11,400 \mathrm{~g}$ supernatant obtained from the reproductive pinnules of D. filix-mas was subjected to streptomycin sulphate treatment at a final concentration of $1.5 \%(\mathrm{w} / \mathrm{v})$ with constant stirring. The mixture was kept at $0^{\circ} \mathrm{C}$ for $30 \mathrm{~min}$ and then centrifuged at $11,400 \mathrm{~g}$ for $20 \mathrm{~min}$. The supernatant (streptomycin sulphate-treated fraction) was collected and fractionated accordingly with 25-70\% $\left(\mathrm{NH}_{4}\right)_{2} \mathrm{SO}_{4}$. The precipitated protein fraction was dissolved and dialyzed overnight using the standard buffer. The ammonium sulphate $(25-70 \%)$ fraction was then loaded onto a column of CM Sephadex C-50 (1.0 x $13.0 \mathrm{~cm}$ ), equilibrated with standard buffer. The effluent was collected. Then the column was washed with one bed volume of the same buffer and the proteins were eluted from the column with a linear gradient of 0.0 to $500 \mathrm{mM}$ $\mathrm{KCl}$ prepared in standard buffer. Fractions of $2.0 \mathrm{~mL}$ were collected at a flow rate of 10 min per fraction (Figure 1). The active CM Sephadex C-50 fractions were pooled and chromatographed on an Ultrogel AcA 34 column ( $0.8 \times 10$ $\mathrm{cm}$ ) and the proteins eluted with the standard buffer. Fractions of $1.0 \mathrm{~mL}$ were collected at a flow rate of $7 \mathrm{~min}$ per fraction (Figure 2). The active fractions of $\mathrm{CM}$ Sephadex C-50 from other batches of purification were pooled and concentrated before the characterization experiments. Active Ultrogel AcA 34 fractions were not chosen for this purpose, as the yield at this step was not appreciable.

Assay of MIPP: The myo-inositol-1-phosphatase activity was assayed by the procedure of Eisenberg Jr (1967) with slight modifications. In a total volume of $1.0 \mathrm{~mL}$, the incubation mixture contained $500 \mu \mathrm{L}$ of $0.67 \mathrm{M}$ Tris- $\mathrm{HCl}$ ( $\mathrm{pH} 7.4$ ) containing $50 \mathrm{mM} \mathrm{MgCl}, 400 \mu \mathrm{L}$ of $154 \mathrm{mM} \mathrm{KCl}$, $50 \mu \mathrm{L}$ of $100 \mathrm{mM}$ D-myo-inositol-1-phosphate and an appropriate protein aliquot $(50 \mu \mathrm{L} / 100-200 \mu \mathrm{g})$. The reaction was started by addition of substrate immediately after the addition of the enzyme. The complete assay mixture was run along with an appropriate blank (without enzyme) and a zero time control in which $250 \mu \mathrm{L}$ of $20 \%$ chilled TCA was added prior to the addition of the 


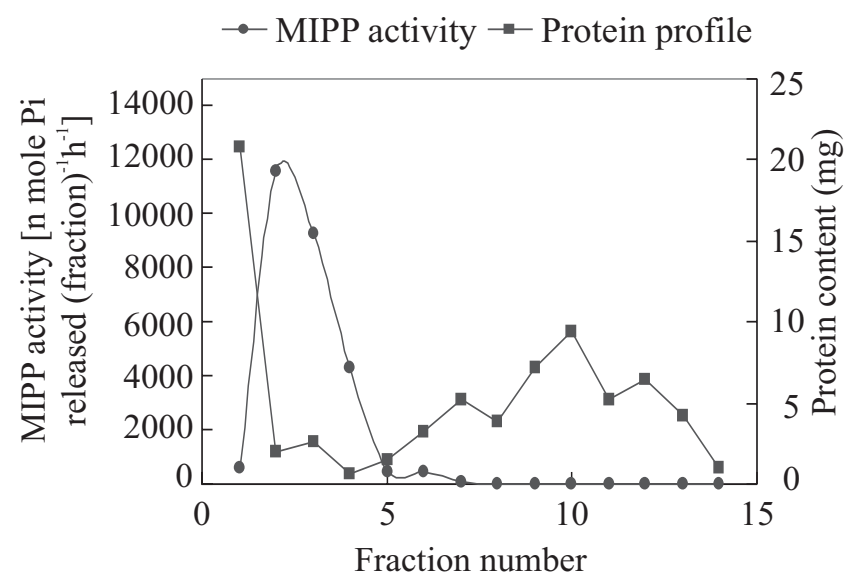

Figure 1. Elution profile of myo-inositol-1-phosphate phosphatase (MIPP) and proteins on a CM Sephadex C50 column.

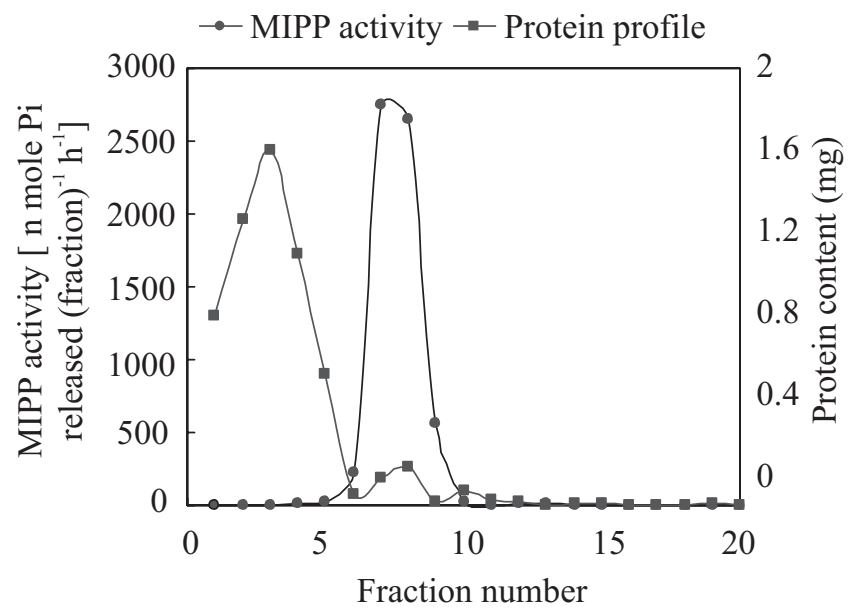

Figure 2. Elution profile of myo-inositol-1-phosphate phosphatase (MIPP) and proteins through a Ultrogel AcA 34 column.

enzyme. The enzymatic incubation was carried out for 60 $\min$ at $37^{\circ} \mathrm{C}$. After $60 \mathrm{~min}$ the reaction was terminated by the addition of $250 \mu \mathrm{L}$ of chilled TCA (20\%). Two such sets (set I - experimental and set II - control, where myoinositol-1-phosphate was replaced by an identical volume and concentration of D-fructose-6-phosphate) were run simultaneously each having one blank, one zero time control and one complete assay mixture. Inorganic phosphate was estimated by the method of Chen et al. (1956) with slight modifications. Protein was determined according to the method of Bradford (1976) with BSA as a standard. As $1 \mathrm{~mol}$ of myo-inositol-1-phosphate contains
1 mol of inorganic phosphate, the total mole number of inorganic phosphate released was equal to the total mole number of myo-inositol-1-phosphate hydrolyzed. The specific activity was defined either as nmol myo-inositol1-phosphate hydrolyzed $\mathrm{mg}^{-1}$ protein $\mathrm{h}^{-1}$ or nmol $\mathrm{P}_{\mathrm{i}}$ released $\mathrm{mg}^{-1}$ protein $\mathrm{h}^{-1}$.

Protein electrophoresis: Polyacrylamide gel electrophoresis of the Ultrogel AcA-34 fraction was performed under non-denaturing conditions using $1.0 \mathrm{~mm}$ gels following the method of Bollag et al. (1996). The protein sample $(\sim 20 \mu \mathrm{g}$ per lane) was loaded onto a gel system containing $8 \%$ separating gel and $4 \%$ stacking gel and electrophoresed in a Biotech regular slab gel apparatus at $4^{\circ} \mathrm{C}$ at $100 \mathrm{~V}$. For MIPP activity in the gels, one of the replicate gels was sliced into $5 \mathrm{~mm}$ fragments and each fragment extracted with $300 \mu \mathrm{L}$ of $50 \mathrm{mM}$ Trisacetate buffer $(\mathrm{pH} 7.5)$ at $0^{\circ} \mathrm{C}$ for $45 \mathrm{~min}$. The extracts were then assayed for MIPP activity. SDS-PAGE was carried out principally according to the method of Laemmli (1970), subject to some necessary modifications, for proteins obtained from the important steps of purification.

Molecluar weight determination: The apparent molecular weight of the native MIPP protein, obtained from the PAGE carried out with the active Ultrogel AcA34 fraction, was determined with the GEL LOGIC 100 IMAGING SYSTEM (Kodak) using the "Molecular imaging software Kodak MI- V.4.0.5". The system was calibrated previously with marker proteins of known molecular weights, namely myosin rabbit muscle (205,000 $\mathrm{kDa})$, phosphorylase b $(97,400 \mathrm{kDa}), \mathrm{BSA}(68,000 \mathrm{kDa})$, ovalbumin $(43,000 \mathrm{kDa})$ and carbonic anhydrase $(29,000$ $\mathrm{kDa})$.

\section{RESULTS}

Diverse representatives of pteridophytes were screened for the presence of MIPP. Table 1 depicts the results of such a survey. As evident, all the vascular cryptogams tested were found to have MIPP activity. The enzyme was functional in vegetative as well as in reproductive parts of the selected species. However, the reproductive parts showed much higher activity in comparison with the vegetative parts of the same species. 
Table 1. Distribution of L-myo-Inositol-1-phosphate phosphatase (MIPP) in some members of pteridophytes. Specific activity was expressed as nmol L-myo-inositol-1-phosphate hydrolyzed $(\mathrm{mg} \text { protein })^{-1} \mathrm{~h}^{-1}$ in a dialyzed $11,400 \mathrm{~g}$ supernatant. Means \pm SE. $n=3$.

\begin{tabular}{|c|c|c|c|c|}
\hline Class & Family & Plant & Plant portion & MIPP specific activity \\
\hline \multirow[t]{4}{*}{ Lycopodiatae } & Lycopodiaceae & Lycopodium clavatum & vegetative & $34 \pm 5.81$ \\
\hline & & & strobili & $70 \pm 11.70$ \\
\hline & Selaginellaceae & Selaginella megaphylla & vegetative & $38 \pm 8.43$ \\
\hline & & & strobili & $74 \pm 12.03$ \\
\hline \multirow[t]{2}{*}{ Equisetatae } & Equisetaceae & Equisetum elongatum & vegetative & $16 \pm 1.73$ \\
\hline & & & strobili & $24 \pm 3.90$ \\
\hline \multirow[t]{10}{*}{ Filicatae } & Polypodiaceae & Polypodium wallichi & vegetative & $40 \pm 6.32$ \\
\hline & & & sori & $229 \pm 23.65$ \\
\hline & Dryopteridaceae & Dryopteris filix-mas & vegetative & $144 \pm 24.27$ \\
\hline & & & sori & $474 \pm 32.91$ \\
\hline & Gleicheniaceae & Diplopterygium glaucum & vegetative & $182 \pm 9.48$ \\
\hline & & & sori & $347 \pm 18.77$ \\
\hline & Hypolepidaceae & Pteridium aquilinum & vegetative & $140 \pm 23.05$ \\
\hline & & & sori & $408 \pm 41.26$ \\
\hline & Gleicheniaceae & Dicranopteris linearis & vegetative & $135 \pm 16.31$ \\
\hline & & & sori & $295 \pm 11.52$ \\
\hline
\end{tabular}

Furthermore, it is also clear from the results of Table 1 that ferns do exhibit higher activities of this enzyme than the lower pteridophytic families on the basis of an evolutionary scale.

As D. filix-mas was readily available and exhibited excellent activity of MIPP in the mature reproductive pinnules, partial purification of MIPP was carried out from this cosmopolitan fern. Table 2 describes the outlines of purification of MIPP. This procedure enabled purification of the enzyme to 41 -fold. The MIPP activity was determined from $5 \mathrm{~mm}$ gel slices after the Ultrogel AcA-34 fraction of D. filix-mas was electrophoresed under non-denaturing conditions. The major band of protein was found to coincide with the enzyme activity (Figure 3). Figure 4 presents the SDS-PAGE profile of the protein in the important and subsequent steps of purification. The apparent molecular weight of the native MIPP was estimated to be $94 \mathrm{kDa}$.

The partially purified $D$. filix-mas MIPP utilized D/Lmyo-inositol-1-phosphate as its substrate (95-100\%), however, about $16 \%$ activity was recorded when D-myoinositol-3-phosphate was used as the substrate. Furthermore, weak (3\%) activity of this MIPP was observed with 2-glycerophosphate as substrate (Table 3 ). The MIPP reaction was linear with time up to $75 \mathrm{~min}$ and protein concentration up to $150 \mu \mathrm{g}$. Fern MIPP exhibited appreciable activity within a temperature range of $20^{\circ} \mathrm{C}$ to $50^{\circ} \mathrm{C}$ having a maximum at $40^{\circ} \mathrm{C}$. The apparent $K_{m}$ value of MIPP for MIP was determined to be $0.083 \mathrm{mM}$ by means of the Michaelis-Menten rate equation. The enzyme was found functional in a narrow $\mathrm{pH}$ range of 7.5 to 8.5 using $0.67 \mathrm{M}$ Tris-HCl buffer (Figure 5). The activity of this MIPP enzyme was remarkably inhibited by the presence of a monovalent cation, lithium, and even moderately so at a low concentration such as $1 \mathrm{mM}$. On the other hand, magnesium, a divalent cation, enhanced activity at least up to $10 \mathrm{mM}$. Calcium diminished MIPP activity at concentrations over $4 \mathrm{mM}$ (Figure 6).

\section{DISCUSSION}

Although MIPP activity has been previously reported for some flowering plant species (Loewus and Loewus 1983; Gumber et al., 1984), no investigation has so far been made to look for this activity among pteridophytes. Results presented here show the existence of MIPP in a variety of vascular cryptogams. Chhetri et al. (2005, 2006) have already established the occurrence of the prime enzyme of myo-inositol biosynthesis, MIPS, in pteridophytes. Therefore, the presence of MIPP adds 
Table 2. Partial purification of cytosolic myo-inositol-1-phosphate phosphatase from the reproductive pinnules of Dryopteris filix-mas. The table represents a typical partial purification obtained from reproductive pinnules (35-37 g) of D. filix-mas. Protein concentration was expressed as $\mathrm{mg} \mathrm{mL}^{-1}$, specific activity as nmol Pi released (mg protein) ${ }^{-1} \mathrm{~h}^{-1}$, and total activity as nmol Pi released $\mathrm{h}^{-1}$. Means \pm SE. $n=3$.

\begin{tabular}{|c|c|c|c|c|c|c|c|}
\hline Fraction & $\begin{array}{l}\text { Total } \\
\text { volume } \\
(\mathrm{mL})\end{array}$ & $\begin{array}{c}\text { Protein } \\
\text { concentration }\end{array}$ & $\begin{array}{l}\text { Total } \\
\text { protein } \\
(\mathrm{mg})\end{array}$ & $\begin{array}{l}\text { Specific } \\
\text { activity }\end{array}$ & $\begin{array}{c}\text { Total } \\
\text { activity }\end{array}$ & Recovery $(\%)$ & $\begin{array}{l}\text { Fold } \\
\text { purification }\end{array}$ \\
\hline $\begin{array}{l}\text { Homogenate } \\
\text { Fraction }\end{array}$ & $72.0 \pm 5.1$ & $1.565 \pm 0.3$ & $112.7 \pm 4.94$ & $467 \pm 24.6$ & $52610 \pm 134$ & $100.00 \pm 6.31$ & $1.00 \pm 0.05$ \\
\hline $\begin{array}{l}11,400 g \text { supernatant } \\
\text { Fraction }\end{array}$ & $61.0 \pm 4.8$ & $1.56 \pm 0.2$ & $95.0 \pm 4.5$ & $471 \pm 24.2$ & $44767 \pm 120$ & $85.08 \pm 5.29$ & $1.00 \pm 0.06$ \\
\hline $\begin{array}{l}\text { Streptomycin } \\
\text { sulphate-treated } \\
\text { Fraction }\end{array}$ & $60.0 \pm 4.2$ & $1.54 \pm 0.2$ & $92.1 \pm 3.9$ & $472 \pm 30.1$ & $43485 \pm 127$ & $82.65 \pm 6.80$ & $1.01 \pm 0.04$ \\
\hline $\begin{array}{l}25-70 \%\left(\mathrm{NH}_{4}\right)_{2} \mathrm{SO}_{4} \\
\text { Fraction }\end{array}$ & $12.4 \pm 0.9$ & $6.01 \pm 0.1$ & $74.6 \pm 0.7$ & $510 \pm 19.6$ & $38044 \pm 325$ & $72.31 \pm 3.16$ & $1.09 \pm 0.03$ \\
\hline $\begin{array}{l}\text { CM Sephadex C-50 } \\
\text { Fraction }\end{array}$ & $8.0 \pm 0.1$ & $0.580 \pm 0.030$ & $4.64 \pm 0.36$ & $4814 \pm 310$ & $22337 \pm 538$ & $42.45 \pm 1.45$ & $10.3 \pm 1.0$ \\
\hline $\begin{array}{l}\text { Ultrogel AcA34 } \\
\text { Fraction }\end{array}$ & $3.0 \pm 0.1$ & $0.104 \pm 0.040$ & $0.312 \pm 0.021$ & $19426 \pm 869$ & $6061 \pm 175$ & $11.51 \pm 2.64$ & $41.6 \pm 4.2$ \\
\hline
\end{tabular}

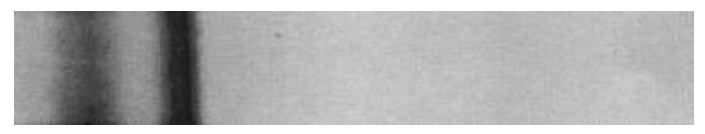

Activity of MIPP in native PAGE

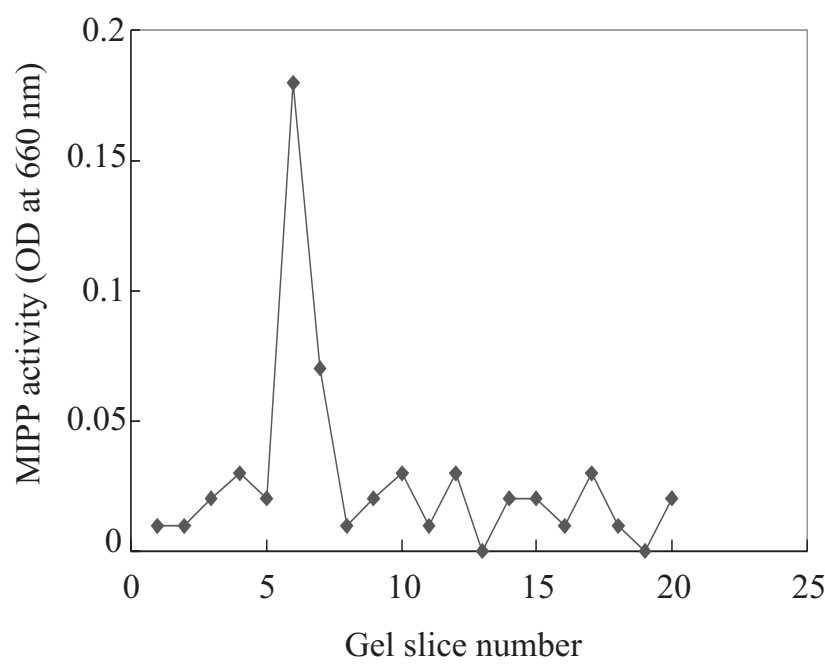

Figure 3. Native PAGE profile showing the myo-inositol1 -phosphate phosphatase (MIPP) activity of the corresponding band.

strength to the ubiquitous occurrence of myo-inositol biosynthesis in pteridophytes. The partial purification of MIPP from D. filix-mas and its preliminary characterization is another step forward towards an understanding of the role of this enzyme in non-flowering vascular plants. Fern MIPP shares some common characteristics, such as substrate specificity, $\mathrm{pH}$ reliance and influence by monovalent cations like lithium, with other reported sources including microbes and mammals (Eisenberg Jr. 1967, Attwood et al., 1988; Gee et al., 1988; Honchar et al., 1989; Leech et al., 1993; Pollack et al., 1994; Caselli et al., 1996, Fujimoto et al., 1996, Nigou and Besra, 2002; Wang et al., 2006; Patra et al., 2007). However, its kinetic parameter, thermo-tolerance and calciumdependent inhibition at lower concentrations, differ substantially in pteridophytic species.

Our concern in the present work has been three-fold. Firstly, MIPP has been reported in a diverse group of living organisms, but not in any pteridophyte. However, MIPS of pteridophytic origin is clearly shown here. Thus, this investigation has filled an obligatory gap in our complete understanding of inositol biosynthesis in pteridophytes with a wide phylogenetic connotation. Secondly, an excellent metabolic and structural synchronization can be established from this present study based on myo-inositol biosynthesis. We have observed previously (Chhetri et al., 2006) that MIPS activity is highest during the early stage of development 


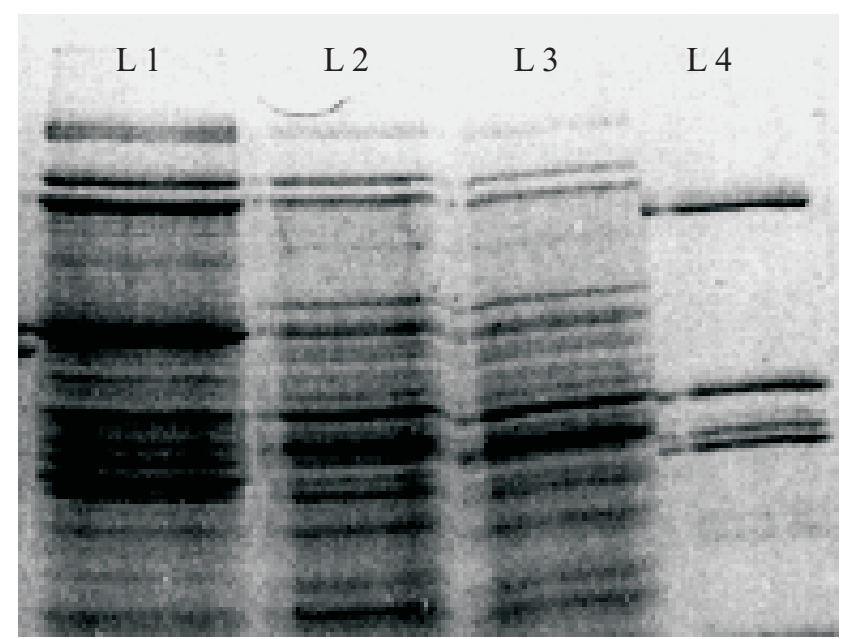

Figure 4. SDS-PAGE profile of proteins after important steps of purification.

Table 3. Substrate specificity of cytosolic myo-inositol-1phosphate phosphatase from Dryopteris filix-mas. Specific activity was expressed as nmol $\mathrm{P}_{\mathrm{i}}$ released $(\mathrm{mg}$ protein $)^{-1} \mathrm{~h}^{-1}$. Concentrations for all substrates were 0.2 mM. Means \pm SE. $n=3$.

\begin{tabular}{lc}
\hline Substrate & Specific activity \\
\hline D-myo-Inositol-1-phosphate & $4538 \pm 352$ \\
L-myo-Inositol-1-phosphate & $4604 \pm 382$ \\
D-myo-Inositol-3-phosphate & $754 \pm 42$ \\
D-Glucose-6-phosphate & 0.00 \\
D-Galactose-6-phosphate & 0.0 \\
2-Glycerophosphate & $307 \pm 23$ \\
\hline
\end{tabular}

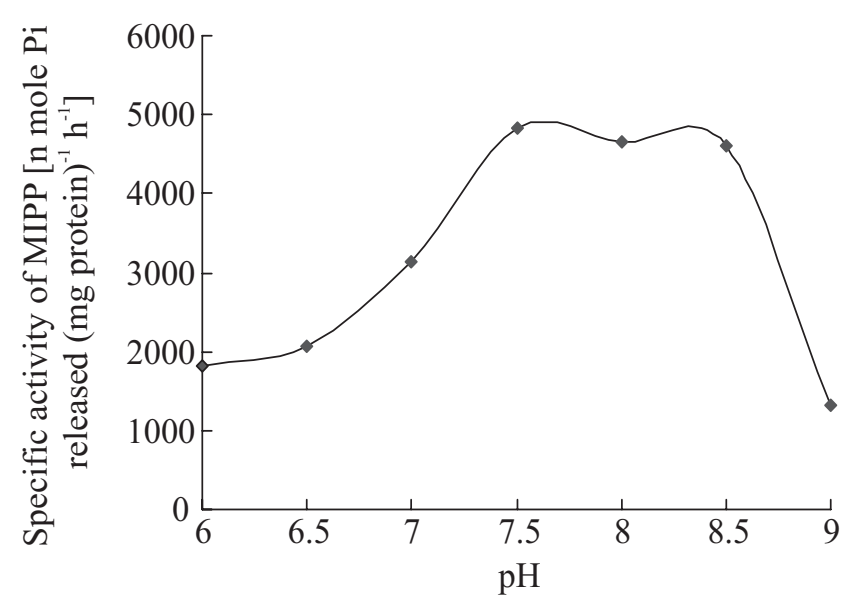

Figure 5. $\mathrm{pH}$ reliance of cytosolic myo-inositol-1phosphate phosphatase (MIPP) activity.

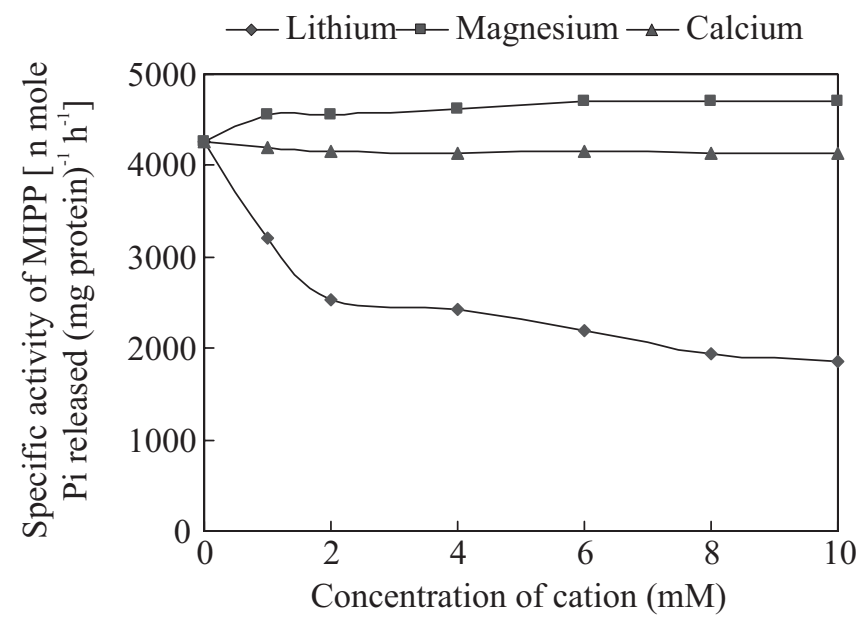

Figure 6. Effect of cations on myo-inositol-1-phosphate phosphatase (MIPP) activity.

of the strobilus or sorus in a pteridophyte. The content of free myo-inositol increases during late stages of development of the strobilus or sorus. Activity of MIPP is also predominant in the mature spore-bearing organs of all the pteridophytes tested. Hence, we can suggest that MIPS triggers the synthesis of L-myo-inositol-1phosphate during the juvenile stage of either stobilus or sorus development in a pteridophyte. This alcohol, myoinositol, on hydrolysis by MIPP at the mature or later stages of strobilus or sorus development to fulfill the requirement of this essential metabolite for the developing spores. Thirdly, the search for MIPP protein can be eloquently achieved either by looking for immunologically cross-reactive material in different systems or more precisely by analysis of nucleotide sequences with the aid of a MIPP gene probe. For both of these techniques a purified enzyme is a pre-requisite. The present work is, therefore, a step forwards towards attaining this goal.

Acknowledgements: Authors are indebted to Prof. K. L. Mukherjee, Former Head of the Department of Biochemistry, IPGMER, Calcutta - 700020, Prof. A. K. Mukherjee, Department of Biotechnology, Bengal College of Engineering and Technology, Bidhan Nagar, Durgapur 713 212, WB, India, for their cooperation. Thanks are also due to Miss N. Mazumdar for her help in statistical data analysis. This work was partially supported by a grant from the DST-FIST, Government of India. 


\section{REFERENCES}

Adhikari J, Majumder AL (1983) Differences in thermal stability of the fetal and adult brain myo-inositol-1phosphate synthase. FEBS Lett. 163:46-49.

Adhikari J, Majumder AL, Bhaduri TJ, Dasgupta S, Majumder AL (1987) Chloroplast as a locale of L-myoInositol-1-phosphate synthase. Plant Physiol. 85:611614.

Adhikari J, Majumder AL (1988) L-myo-inositol-1phosphate synthase from mammalian brain: partial purification and characterization of the fetal and adult enzyme. Ind. J. Biochem. Biophys. 25:408-412.

Attwood PV, Ducep JB, Chanal MC (1988) Purification and properties of myo-inositol-1-phosphatase from bovine brain. Biochem. J. 253:387-394.

Bachhawat N, Mande SC (2000) Complex evolution of the inositol-1-phosphate synthase gene among archea and eubacteria. Trends Genet. 16:111-113.

Benaroya RO, Zamski E, Tel-Or E (2004) L-myo-inositol-1phosphate synthase in the aquatic fern Azolla filiculoides. Plant Physiol. Biochem. 42:97-102.

Bollag DM, Rozycki MD, Edelstein SJ (1996) Protein Methods. $2^{\text {nd }}$ ed. Wiley-Liss, New York.

Bradford MM (1976) A rapid and sensitive method for the quantitation of microgram quantities of proteins utilizing principle of protein-dye binding. Anal. Biochem. 72:248-254.

Caselli A, Cirri P, Bonifacio S, Manao G, Camici G, Cappugi G, Moneti G, Ramponi G. (1996) Identity of zinc iondependent acid phosphatase from bovine brain and myo-inositol 1-phosphatase. Biochim. Biophys. Acta 1290:241-249.

Chen L, Zhou C, Yang H, Roberts MF (2000) Inositol-1phosphate synthase from Archaeoglobus fulgidus is a class II aldolase. Biochemistry 39:12415-12423.

Chen RS, Toribara TY, Warner H (1956) Microdetermination of phosphorous. Anal. Chem. 28:1756-1758.

Chettri DR, Choudhuri M, Mukherjee AK, Adhikari J (2005) L-myo-inositol-1-phosphate synthase: partial purification and characterisation from Gleichenia glauca. Biol. Plant. 49:59-63.

Chhetri DR, Mukherjee AK, Adhikari J (2006) Myoinositol content in pteridophytes and the isolation and characterization of L-myo-inositol-1-phosphate synthase from Diplopterygium glaucum. Braz. J. Plant Physiol. 18: 291-298.
Chiu TT, Rogers MS, Briton-Jones C, Haines C (2003) Effects of myo-inositol on the in-vitro maturation and subsequent development of mouse oocytes. Hum. Reprod. 18:408-816.

Chun JA, Jin UH, Lee JW, Yi YB, Hyung NI, Kang MH, Pyee JH, Suh MC, Kang CW, Seo HY, Lee SW, Chung $\mathrm{CH}$ (2003) Isolation and characterization of a myoinositol 1-phosphate synthase cDNA from developing sesame (Sesamum indicum L.) seeds: functional and differential expression, and salt-induced transcription during germination. Planta 216:874-880.

Dasgupta S, Adhikari J, Majumder AL (1984) L-myoinositol-1-phosphate synthase from lower plant groups: purification and properties of the enzyme from Euglena gracilis. Physiol. Plant. 61:412-416.

Donahue TF, Henry SA (1981a) Inositol mutants of Saccharomyces cerevisiae: Mapping the INO1 locus and characterizing alleles of INO1, INO2 and INO4 loci. Genetics 98:491-503.

Donahue TF, Henry SA (1981b) Myo-inositol-1phosphate synthase: Characteristics of the enzyme and identification of its structural gene in yeast. J. Biol. Chem. 256:7077-7085.

Eisenberg F Jr (1967) D-myo-Inositol-1-phosphate as product of cyclization Glucose-6-phosphate and substrate for a specific phosphatase in rat testis. J. Biol. Chem. 242:1375-1382.

Escamilla JE, Contreas M, Martinez A, Pina MZ (1982) Lmyo-Inositol-1-phosphate synthase from Neurospora crassa: Purification to homogeneity and partial characterization. Arch. Biochem. Biophys. 218:275-285.

Fujimoto S, Okano I, Tanaka Y, Sumida Y, Tsuda J, Kawakami N, Shimohama S (1996) Zinc-ion-dependent acid phosphatase exhibits magnesium-ion-dependent myo-inositol-1-phosphatase activity. Biol. Pharma. Bull. 19:882-885.

Gee NS, Ragan CI, Watling KJ, Aspley S, Jackson RG, Reid GG, Gani D, Shute JK (1988) The purification and properties of myo-inositol monophosphatase from bovine brain. Biochem. J. 249:883-889.

Gumber SC, Loewus MW, Loewus FA (1984) Myoinositol-1-phosphate synthase from pine pollen: Sulfhydryl involvement at the active site. Arch. Biochem. Biophys. 231:372-377.

Honchar MP, Ackermann KE, Sherman WR (1989) Chronically administered lithium alters neither myoinositol monophosphatase activity nor phosphoinositide levels in rat brain. J. Neurochem. 53:590-594. 
IUPAC (1976) Nomenclature of Cyclitols. Biochem. J. 153:23-31.

Johnson MD, Sussex IM (1995) 1L-myo-Inositol 1phosphate synthase from Arabidopsis thaliana. Plant Physiol. 107:613-619.

Johnson MD, Wang X (1996) Differentially expressed forms of 1-L-myo-Inositol 1-phosphate synthase (EC. 5.5.1.4) in Phaseolus vulgaris. J. Biol. Chem. 271:17215-17218.

Kwok F, Lo SC (1994) Development of a continuous coupled enzymatic assay for myo-inositol monophosphatase. J. Biochem. Biophys. Meth. 29:173-178.

Lackey KH, Pope PM, Johnson MD (2003) Expression of 1L-myo-inositol-1-phosphate synthase in organelles. Plant Physiol. 132:2240-2247.

Laemmli UK (1970) Cleavage of structural proteins during the assembly of the head of bacteriophage $T_{4}$ Nature 227:680-685.

Leech AP, Baker GR, Shute JK, Cohen MA, Gani D (1993) Chemical and kinetic mechanism of the inositol monophosphatase reaction and its inhibition by $\mathrm{Li}^{+}$. Eur. J. Biochem. 12:693-704.

Loewus MW, Loewus FA (1971) The isolation and characaterisation of D-Glucose 6-phosphate cycloaldolase (NAD-dependent) from Acer pseudoplatanus L. cell cultures. Plant Physiol. 48:255-260.

Loewus FA, Loewus MW, Maity IB, Rosenfield CL (1978) Aspects of myo-inositol metabolism and biosynthesis in higher plants. In: Wells WW, Eisenberg F Jr (eds), Cyclitols and Phosphoinositides, pp.249-267. Academic Press, New York.

Loewus FA, Loewus MW (1983) Myo-Inositol: its biosynthesis and metabolism. Annu. Rev. Plant Physiol. 34:137-161.

Lohia A, Hait NC, Majumder AL (1999) L-myo-inositol 1phosphate synthase from Entamoeba histolytica. Mol. Biochem. Parasitol. 98:67-79.

Maeda T, Eisenberg F Jr (1980) Purification, structure and catalytic properties of the 1 L-myo-inositol-1phosphate synthase from rat testis. J. Biol. Chem. 255:8458-8464.

Nigou SJ, Besra G (2002) Characterization and regulation of inositol monophosphatase activity in Mycobacterium smegmatis. Biochem. J. 361:385-390.

Ogunyemi O, Pittner F, Hoffman-Ostenhof O (1978) Studies on the biosynthesis of cyclitols. XXXVI. Purification of myo-inositol-1-phosphate synthase of the duckweed Lemna gibba to homogeneity by affinity chromatography on NAD sepharose. Molecular and catalytic properties of the enzyme. Hoppe-Seyler's Z. Physiol. Chem. 359:613-616.

Patra B, Ghosh-Dastidar K, Maitra S, Bhattacharyya J, Majumder AL (2007) Functional identification of sll1383 from Synechocystis sp. PCC 6803 as L-myoinositol 1-phosphate phosphatase (EC 3.1.3.25): molecular cloning, expression and characterization. Planta 225:1547-1558.

Pittner F, Hoffman-Ostenhof O (1976) Studies on the biosynthesis of Cyclitols. XXXV. On the mechanism of action of myo-inositol 1-phosphate synthase from rat testicles. Hoppe-Seyler's Z. Physiol. Chem. 357:16671671.

Pollack SJ, Atack JR, Knowles MR, McAllister G, Ragan CI, Baker R, Fletcher SR, Iversen LL, Broughton HB (1994) Mechanism of inositol monophosphatase, the putative target of lithium therapy. Proc. Natl. Acad. Sci. USA 91:5738-5739.

RayChoudhury A, Hait NC, Dasgupta S, Bhaduri TJ, Deb R, Majumder AL (1997) L-myo-inositol 1phosphate synthase of plant sources. Plant Physiol. 115:727-736.

Wang YK, Morgan A, Stieglitz K, Stec B, Thompson B, Miller SJ, Roberts MF (2006) The temperature dependence of the inositol monophosphatase $\mathrm{Km}$ correlates with accumulation of D/L-myo-inositol 1, 1'phosphate in Archaeoglobus fulgidus. Biochemistry 45:3307-3314. 